\title{
Characterization of Diazepam Imprinted Polymer with Methacrylic Acid and Hydroxyethyl Methacrylate Monomer in Chloroform for Selective Adsorption of Diazepam
}

\author{
Michelle Ferdinand, Rimadani Pratiwi, Aliya N. Hasanah* \\ Departemen Analisis Farmasi dan Kimia Medisinal, Fakultas Farmasi, Universitas Padjadjaran, Jalan Raya Bandung \\ Sumedang KM 21, Jatinangor, Sumedang 45363
}

Submitted 12 February 2020; Revised 27 February 2020; Accepted 27 February 2020; Published 10 June 2020

*Corresponding author:aliya.n.hasanah@unpad.ac.id

\begin{abstract}
Diazepam is a benzodiazepine class usage is regulated nationally or globally. Monitoring the abuse of diazepam requires a sensitive analysis methods that required the preparation of selective methods. One of the methods that are currently developing is Moleculary Imprinted Polymer-Solid Phase Extraction (MI-SPE). In this research, step being performed include determination of the association constant, synthesis sorbent of Imprinted Polymer (IP) diazepam by bulk polymerization method with two kind of monomer methacrylic acid (MAA) and hydroxyethyl methacrylate (HEMA) as functional monomer. Templates extracted from polymer followed by evaluation of adsorption ability test, a test of capacity and selectivity of the polymer, and also the characterization of the IP. The results showed that IP diazepam with MAA monomer has $7.95 \times 10^{-5} \mathrm{mg} / \mathrm{g}$ of capacity, it is better than capacity of IP diazepam monomer HEMA with $7.48 \times 10^{-6} \mathrm{mg} / \mathrm{g}$. Selectivity of IP diazepam MAA monomer has an IF value which is 2.13 , which is better than IP HEMA with 1.21. In addition, IP diazepam MAA monomer more heterogenous than its Non Imprinted Polymer (NIP).
\end{abstract}

Keywords: Chloroform, Diazepam, HEMA, Methacrylic acid, MI-SPE

\section{Karakterisasi Imprinted Polymer Diazepam Monomer Asam Metakrilat dan Hidroksietil Metakrilat dalam Kloroform untuk Adsorpsi Selektif Diazepam}

\begin{abstract}
Abstrak
Diazepam adalah golongan benzodiazepin yang penggunaannya diawasi secara nasional maupun global. Monitoring penyalahgunaan diazepam memerlukan metode analisis yang sensitif sehingga dibutuhkan metode preparasi selektif. Salah satu metode yang saat ini berkembang adalah Moleculary Imprinted Polymer-Solid Phase Extraction (MI-SPE). Pada penelitian ini, tahapan meliputi penentuan konstanta asosiasi, pembuatan sorben imprinted polymer (IP) diazepam metode polimerisasi ruah dengan monomer asam metakrilat (MAA) dan hidroksi etil metakrilat (HEMA). Template diekstraksi dari polimer yang dilanjutkan dengan evaluasi uji kemampuan adsorpsi, uji kapasitas dan selektivitas IP, serta karakteristik IP. Hasil menunjukkan bahwa IP diazepam monomer asam metakrilat mempunyai kapasitas adsorpsi $7,95 \times 10^{-5} \mathrm{mg} / \mathrm{g}$ yang lebih baik dibandingkan IP diazepam monomer HEMA dengan kapasitas adsorpsi sebesar 7,48 x 10-6 $\mathrm{mg} / \mathrm{g}$. Selektivitas IP diazepam monomer asam metakrilat lebih baik dibandingkan IP HEMA dengan nilai IF sebesar 2,13 sedangkan IP HEMA sebesar 1,21. Selain itu, MIP diazepam monomer asam metakrilat memiliki rongga yang lebih heterogen dibandingkan Non Imprinted Polymer (NIP).
\end{abstract}

Kata Kunci: Asam metakrilat, diazepam, HEMA, kloroform, MI-SPE 


\section{Pendahuluan}

Diazepam merupakan obat yang tergolong ke dalam senyawa benzodiazepin yang penting. Tiga senyawa benzodiazepin yang termasuk penting yaitu diazepam, lorazepam dan midazolam. ${ }^{1}$ Diazepam digunakan untuk terapi dalam ansietas atau kecemasan dengan penggunaan jangka lama karena memiliki masa kerja yang panjang. ${ }^{2}$ Peraturan Menteri Kesehatan Nomor 3 tahun 2017, menyebutkan bahwa diazepam termasuk ke dalam Psikotropika Golongan IV. Penggunaan diazepam diawasi oleh pihak tenaga kesehatan baik secara nasional maupun global sehingga jika diperlukan dalam pelayanan kesehatan maka harus ada rujukan. Hal ini sudah tercantum dalam Undang - undang Nomor 5 tahun 1997 tentang Psikotropika dan Convention on Psychotropic Substance in 1971. Diazepam mampu menimbulkan efek ketergantungan dan sering disalahgunakan bersama dengan narkotika opioid, alkohol maupun benzodiazepin related drugs (z-drugs) seperti zopiclon, zaleplon dan zolpidem. ${ }^{3}$ Tindak pidana penggunaan narkotika dan psikotropika dengan persentase penggunaan diazepam sebagai psikotropika golongan IV adalah 7,69 \% dari 76 orang pada tahun $2016 .{ }^{4}$

Selain itu, di Tanzania tercatat $70 \%$ dari 161 apotek memberikan diazepam tanpa resep. ${ }^{5}$ Penggunaannya dalam dosis normal diberikan kepada penderita gangguan tidur dengan dosis harian rata - rata adalah $15 \mathrm{mg}$. Diazepam yang sudah dikonsumsi akan berada di dalam darah dengan kadar 0,11 - 0,83 $\mathrm{mg} / \mathrm{L}$ dan dalam serum atau plasma dengan kadar 0,2 - 1,5 mg/L. ${ }^{6}$ Maka dari itu perlu dilakukan analisis zat aktif untuk mengetahui keberadaannya dalam sampel biologis seseorang yang dapat mendeteksi keberadaan diazepam yang cukup rendah dalam serum. Analisis zat aktif dalam sampel biologis memerlukan metode preparasi yang selektif agar metode analisis dapat ditingkatkan sensitivitasnya. Preparasi sampel dari sampel biologis yang saat ini sering dilakukan adalah solid phase extraction (SPE). SPE adalah metode ekstraksi menggunakan fase padat sebagai fase diam dan fase cair sebagai fase bergerak. Keunggulan menggunakan metode ini adalah lebih mudah digunakan dibandingkan ekstraksi konvensiona; (seperti ekstraksi cair cair (ECC)). Namun metode ini memiliki kekurangan yaitu kapasitas dalam preparasi masih kurang selektif terhadap analit karena dapat membentuk ko-ekstraksi antara pengganggu dan analit. Oleh karena itu metode ini dikombinasikan dengan Molecularly Imprinted Polymer (MIP). ${ }^{7}$ Molecular imprinted polimer (MIP) adalah teknik sintesis atau pembuatan polimer yang memiliki rongga akibat penghilangan template. Rongga tersebut berfungsi untuk mengenali molekul dengan ukuran, struktur, kimia, dan sifat fisik yang sama dengan template. $^{7}$ Sintesis MIP menggunakan metode polimerisasi ruah karena mudah dilakukan dibandingkan metode polimerisasi lainnya dan titik didih kloroform yang cukup rendah menunjukkan kloroform sesuai untuk digunakan dalam metode polimerisasi ruah tetapi tidak dapat digunakan dalam polimerisasi pengendapan. Dalam proses ini digunakan porogen kloroform termasuk pelarut non polar yang mudah melarutkan template diazepam. Monomer yang digunakan adalah asam metakrilat yang dapat berinteraksi kuat dengan template dalam berbagai interaksi (ikatan hidrogen donor-akseptor, ikatan dipol - dipol, dan van der Waals). ${ }^{8}$ Asam metakrilat (MAA) biasanya digunakan sebagai monomer dalam imprinting non - kovalen yang mampu berinteraksi dengan gugus fungsional seperti ester, asam, amida, dan amina. ${ }^{9}$ Selain itu, kombinasi asam metakrilat sebagai monomer dengan pelarut non polar sebagai porogen akan menghasilkan ikatan hidrogen dan interaksi elektrostatik yang berpengaruh terhadap imprinting (pencetakan). ${ }^{10}$ Begitu pula dengan hidroksi etil metakrilat (HEMA) yang memiliki gugus hidroksil sehingga memiliki sifat hidrofilik. ${ }^{11}$ Penelitian ini dilakukan dengan tujuan mengetahui kinerja analitik dan karakterisasi dari sorben MI-SPE diazepam dengan porogen kloroform dan monomer asam metakrilat dan hidroksi etil metakrilat (HEMA). 


\section{Metode}

2.1. Alat

Agitator (IKA®HS 260 basic), ayakan mesh 60, Fourier Transform Infrared (FTIR) (Shimadzu, IR Prestige-21), mikropipet (HumaPette) ukuran 1-10 $\mu \mathrm{L} ; 10-100 \mu \mathrm{L}$; 100-1000 $\mu \mathrm{L}$, oven (Memmert), Scanning Electron Microscope (JEOL JSM 6510LA), sentrifugasi (Yenaco dan Hettich), spektrofotometer UV-Vis (Analytik jena, specord 200), timbangan digital (OHAUS Pioneer), ultrasonik (NEY 19H), waterbath (Memmert) dan alat-alat gelas yang umum digunakan di laboratorium.

\subsection{Bahan}

Alprazolam (Sigma), asam metakrilat (Sigma Aldrich), asam asetat glasial, asetonitril (Fisher Scientific), benzoil peroksida (Merck), diazepam (TCI), dimetil sulfoksida (DMSO) (Merck), etanol (Merck), etilen glikol dimetakrilat (EGDMA) (Sigma Aldrich), hidroksi etil metakrilat (HEMA) (Sigma Aldrich), hidromorfon $\mathrm{HCl}$ (Dilaudid), kalium bromida (Merck), kloroform (Merck), dan semua bahan yang digunakan memiliki grade pro analisis.

\subsection{Prosedur}

Metode pada penelitian ini meliputi penentuan konstanta asosiasi monomer template dengan menggunakan spektrofotometer UV Visible, sintesis sorben MIP dan NIP diazepam dengan metode polimerisasiruah, ekstraksitemplatediazepam dari sorben MIP-SPE yang disintesis dengan cara sonikasi, evaluasi kemampuan adsorpsi sorben Molecular Imprinted Polymer (MIP) dan Non Imprinted Polymer (NIP) dengan metode batch, evaluasi kapasitas adsorpsi sorben MIP dan NIP dengan metode batch, penentuan selektivitas sorben MIP dan NIPSPE, serta penentuan karakteristik secara fisika MIP dan NIP dengan Fourier Transform Infra Red (FTIR), dan Scanning Electron Microscope (SEM).

Penentuan Konstanta Asosiasi Monomer-Template dengan Menggunakan Spektrofotometer UV Visible. Penentuan konstanta asosiasi dilakukan dengan menggunakan metode titrasi spektrofotometer UV-Vis yang mengacu pada penelitian Song et al (2008) dengan beberapa modifikasi. Larutan diazepam 4 x $10-6 \mathrm{mmol} / \mathrm{mL}$ dilarutkan dengan pelarut kloroform yang kemudian dimasukkan ke dalam kuvet sebanyak 2,5 mL. Kemudian ditambahkan larutan monomer asam metakrilat 1 x 10-2 $\mathrm{mmol} / \mathrm{mL}$ secara bertingkat dan terus menerus mulai dari $10 \mu \mathrm{L}, 20 \mu \mathrm{L}, 30 \mu \mathrm{L}, 50 \mu \mathrm{L}$, dan $100 \mu \mathrm{L}$. Setiap penambahan monomer asam metakrilat dicatat absorbansi yang didapatkan dari pengukuran menggunakan dan diukur dengan menggunakan spektrofotometer UV. Penambahan larutan asam metakrilat dihentikan setelah tidak terjadi penambahan absorbansi yang signifikan. Perlakuan yang sama diulangi pada monomer hidroksi etil metakrilat (HEMA). Kemudian dibuat grafik hubungan antara $1 /[\mathrm{G}]$ dengan $1 / \Delta \mathrm{Y}$ dan dihitung nilai konstanta asosiasi dengan persamaan Benesi-Hildebrand :

$$
\frac{1}{\Delta \mathrm{Y}}=\frac{1}{\mathrm{Y} \Delta \mathrm{HGKa}[\mathrm{G}]}+\frac{1}{\mathrm{Y} \Delta \mathrm{HG}}
$$

$\Delta \mathrm{Y}$ merupakan perubahan absorbansi, $\mathrm{Y} \Delta \mathrm{HG}$ merupakan perubahan absorbansi $\mathrm{HG}$ - absorbansi H, [G] merupakan konsentrasi monomer yang ditambahkan, dan $\mathrm{Ka}$ merupakan konstanta asossiasi (M-1). ${ }^{12}$

Sintesis Molecular Imprinted Polymer (IP) dan Non Imprinted Polymer (NIP) dengan Metode Polimerisasi Ruah. Metode pembuatan sintesis polimer ini mengacu pada penelitian Nurhayati et al., $2016^{13}$ serta Ansari dan Ghorbani, 2017 14 dengan beberapa modifikasi. Diazepam 1 mmol (template) sebanyak 0,28476 gram dilarutkan dalam 3,5 mL kloroform dalam vial tertutup dan disonikasi selama 5 menit hingga diazepam larut, dibuat duplo untuk monomer berbeda. Vial pertama ditambahkan monomer asam metakrilat 4 mmol sebanyak $339 \mu \mathrm{L}$ lalu disonikasi selama 5 menit. Selain itu, pada vial kedua ditambahkan monomer $4 \mathrm{mmol}$ HEMA sebanyak $500 \mu \mathrm{L}$ yang lalu disonikasi selama 5 menit. Pada tiap vial ditambahkan 
EGDMA 20 mmol (cross linker) sebanyak 3,77 $\mathrm{mL}$ dan disonikasi selama 10 menit. Benzoil peroksida sebagai inisiator sebanyak $250 \mathrm{mg}$ ditambahkan dan disonikasi selama 20 menit (hingga larut). Vial diseal dengan menggunakan parafilm dan dipanaskan di dalam oven dengan suhu $70^{\circ} \mathrm{C}$ selama 1 jam. Vial kemudian dipindahkan ke dalam waterbath shaker dengan suhu $70^{\circ} \mathrm{C}$ selama 18 jam. Polimer yang terbentuk digerus lalu diayak dengan mesh nomor 60. Polimer dicuci dengan menggunakan etanol dan air, setelah itu polimer dikeringkan dalam oven dengan suhu $55^{\circ} \mathrm{C}$ selama 18 jam. Pengerjaan ini juga dilakukan pada NIP dengan prosedur yang sama, tetapi tanpa adanya penambahan diazepam (template).

\section{Ekstraksi Template Diazepam} dari Sorben IP Cara Sonikasi. Ekstraksi template dilakukan dengan metode sonikasi seperti Ju et. al. (2007). Serbuk IP sebanyak 1 $\mathrm{g}$ dilarutkan dalam $50 \mathrm{~mL}$ etanol : asam asetat $(9: 1, \mathrm{v} / \mathrm{v})$ yang diekstraksi menggunakan alat ultrasonik selama 30 menit. Pelarut yang diberikan dalam kondisi segar dan pengerjaan dilakukan mencapai 10 kali tergantung kebutuhan. Menurut Hasanah et al., (2015) ${ }^{15}$ Sorben kemudian dikeringkan di dalam oven dengan suhu $55^{\circ} \mathrm{C}$ selama 18 jam. Untuk memastikan template telah terekstraksi, dilakukan monitoring dengan cara $20 \mathrm{mg}$ MIP ditambahkan $5 \mathrm{~mL}$ etanol kemudian diukur absorbansinya menggunakan spektrofotometer UV Visible. Jika telah bebas dari template, polimer dicuci dengan $50 \mathrm{~mL}$ etanol : aquadest $(1: 1)$.

Evaluasi Kemampuan Adsorpsi IP dan NIP dengan Metode Batch. Evaluasi kemampuan adsorpsi dari MIP dan NIP dengan metode batch dapat dilakukan mengacu pada penelitian Hasanah et al (2015) $)^{15}$ dengan beberapa modifikasi. Diazepam $5 \mathrm{mg} / \mathrm{L}$ dibuat dalam berbagai macam pelarut, yaitu kloroform, asetonitril, dan dimetil sulfoksida (DMSO). Kemudian larutan diazepam 5 $\mathrm{mg} / \mathrm{L}$ sebanyak $5 \mathrm{~mL}$ ditambahkan ke dalam vial yang berisi $20 \mathrm{mg}$ sorben IP, kemudian dilakukan agitasi selama 3 jam, pengerjaan ini dilakukan secara triplo. Blanko yang digunakan yaitu berisi sorben $40 \mathrm{mg}$ MIP sebanyak $10 \mathrm{~mL}$ pelarut dengan agitasi selama 3 jam. Campuran selanjutnya didekantasi dan dilakukan pengukuran absorbansi filtrat menggunakan spektrofotometer UV Visible. Jumlah diazepam yang terabsorpsi dihitung berdasarkan selisih konsentrasi awal diazepam dan konsentrasi diazepam akhir dalam filtrat. Pengerjaan ini juga dilakukan pada NIP dengan prosedur yang sama.

Penentuan Selektivitas IP dan NIP dengan Metode Batch. Penentuan seletivitas dari IP dan NIP dapat ditentukan dengan metode yang telah dilakukan oleh Hasanah et al (2014) $)^{16}$ dengan beberapa modifikasi. Adsorpsi dilakukan terhadap larutan diazepam, alprazolam, dan hidromorfon dengan konsentrasi $5 \mathrm{mg} / \mathrm{L}$ sebanyak $5 \mathrm{~mL}$ dari masing-masing larutan zat dimasukkan ke dalam vial berbeda yang telah berisi 20 mg sorben MIP kemudian dilakukan agitasi selama 3 jam, pengerjaan ini dilakukan secara triplo. Pada blanko, sebanyak $40 \mathrm{mg}$ sorben IP dengan $10 \mathrm{~mL}$ pelarut tanpa diazepam dilakukan agitasi selama 3 jam. Filtrat dari hasil dekantasi diukur absorbansinya menggunakan spektrofotometer UV Visible. Pengerjaan ini juga dilakukan pada NIP. Data penentuan selektivitas dihitung menggunakan rumus koefisien distribusi dan imprinting factor.

$$
K D=\frac{(C i-C f) v}{C f m}
$$

KD adalah koefisien distribusi, $\mathrm{Ci}$ adalah konsentrasi larutan awal $(\mathrm{mg} / \mathrm{L}), \mathrm{Cf}$ adalah konsentrasi larutan akhir (mg/L), v adalah volume larutan $(\mathrm{mL})$, dan $\mathrm{m}$ adalah massa sorben (g) (Liu et al., 2008).

$$
\mathrm{IF}=\mathrm{KD} \text { IP / KD NIP }
$$

IF merupakan imprinting factor, KD IP adalah koefisien distribusi IP, dan KD NIP adalah koefisien distribusi NIP. ${ }^{16}$

Karakterisasi secara Fisika Sorben IP dan NIP dengan Fourier Transform 


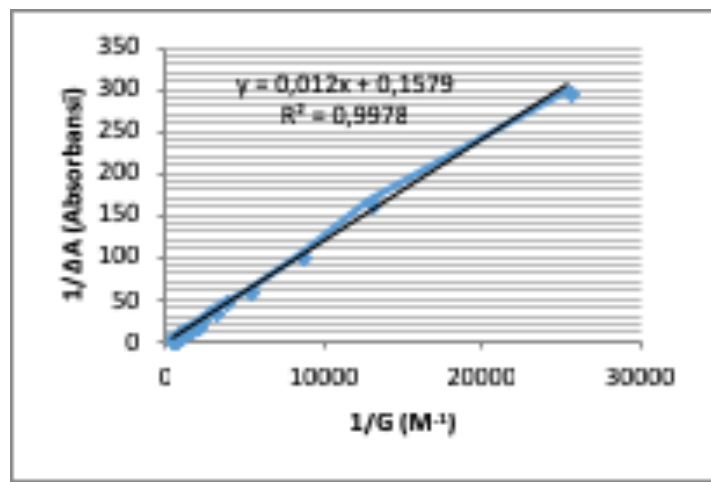

(a)

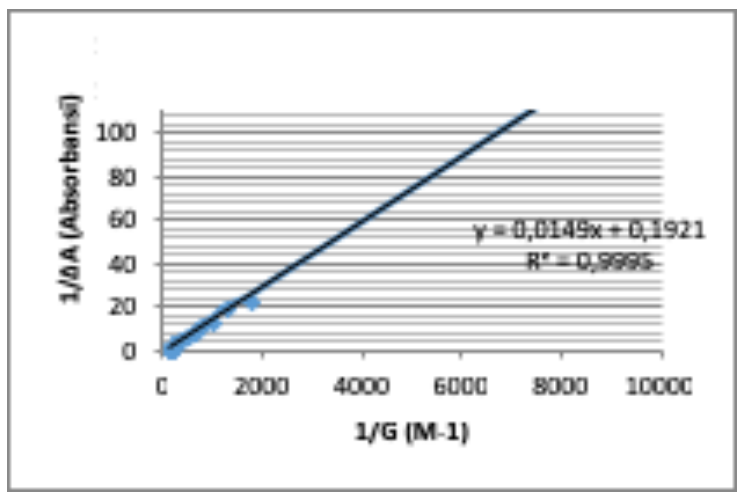

(b)

Gambar 1. Kurva penentuan konstanta asosiasi antara diazepam dengan asam metakrilat (a), dan HEMA (b)

Infra Red (FTIR), dan Scanning Electron Microscope (SEM). Penentuan karakterisasi secara fisika dari sorben IP dan NIP menggunakan metode yang mengacu pada Hasanah et. al. $(2015)^{15}$ sorben IP sebanyak $2 \mathrm{mg}$ digerus bersama dengan $200 \mathrm{mg}$ kalium bromida $(\mathrm{KBr})$ kemudian dicetak menjadi pelet. Spektrum inframerah sorben IP diamati dengan menggunakan instrumen FTIR. Transmisi diukur pada bilangan gelombang 4000 - $400 \mathrm{~cm}-1$. Penentuan gugus fungsi sorben IP ini dilakukan sebelum dan sesudah ekstraksi dengan cara metode sonikasi. Pengerjaan ini juga dilakukan pada NIP dengan prosedur yang sama. Penentuan morfologi ini dilakukan dengan alat SEM yaitu merekatkan double tip karbon pada specimen holder yang kemudian ditaburkan sorben IP dan NIP secukupnya pada bagian atasnya dan dilanjutkan dengan pembacaan dengan SEM. Pengamatan dilakukan dengan mengatur perbesaran sesuai yang diinginkan. ${ }^{17}$

\section{Hasil}

3.1. Penentuan Konstanta Asosiasi Monomer-Template dengan Menggunakan Spektrofotometer UV Visible

Penentuan konstanta asosiasi ini dilakukan berdasarkan interaksi antara monomer (asam metakrilat maupun dengan HEMA) dengan template diazepam. Setiap penambahan monomer diukur serapannya dan dihitung konstanta asosiasinya menggunakan persamaan Benesi-Hildebrand. Konstanta asosiasi dihitung dari intersep dibanding slope yang didapatkan. Berdasarkan Gambar 1a., didapatkan nilai konstanta asosiasi diazepam

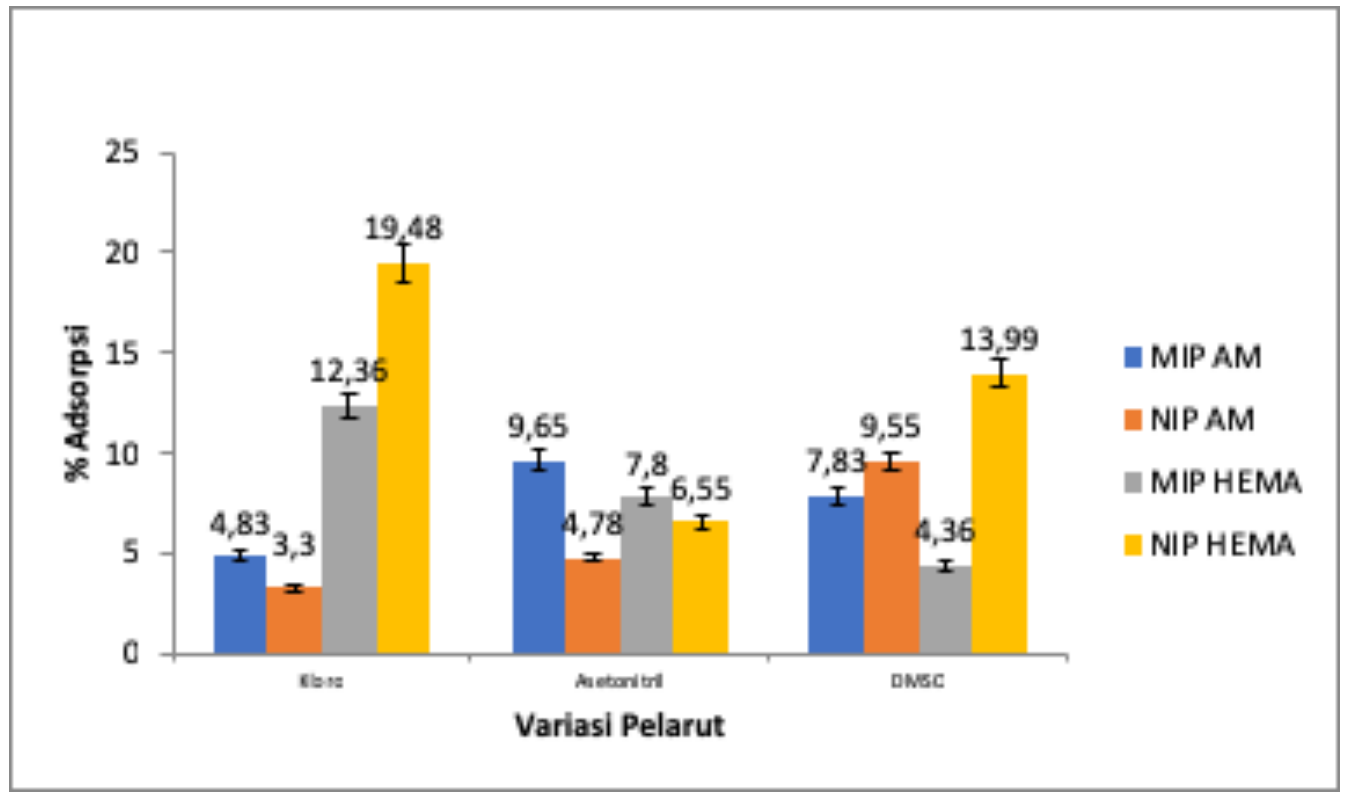

Gambar 1. Hasil kemampuan adsorpsi sorben 
Tabel 1. Hasil evaluasi kapasitas adsorpsi menggunakan Isoterm Freundlich dan Langmuir

\begin{tabular}{|c|c|c|c|c|c|c|}
\hline \multirow[t]{2}{*}{ Polimer } & \multicolumn{3}{|c|}{ Isoterm Freundlich } & \multicolumn{3}{|c|}{ Isoterm Langmuir } \\
\hline & $\mathrm{m}$ & A & $\mathrm{R}^{2}$ & $\mathrm{~b}$ & $\mathrm{~K}$ & $\mathrm{R}^{2}$ \\
\hline MIP AM & 1,2685 & $7,954 \times 10^{-5}$ & 0,9744 & $-0,003247$ & $-0,03192$ & 0,5545 \\
\hline NIP AM & 1,7391 & $1,327 \times 10^{-5}$ & 0,8697 & $-0,000508$ & $-0,05998$ & 0,6143 \\
\hline MIP HEMA & 2,4913 & $7,479 \times 10^{-6}$ & 0,9916 & $-0,000147$ & $-0,13454$ & 0,8856 \\
\hline NIP HEMA & 2,2611 & $1,023 \times 10^{-5}$ & 0,9998 & $-0,000185$ & $-0,12513$ & 0,9927 \\
\hline
\end{tabular}

monomer asam metakrilat sebesar 13,16 $\mathrm{M}^{-1}$. Sedangkan pada Gambar 1b., diazepam monomer HEMA didapatkan nilai konstanta asosiasi sebesar $12,89 \mathrm{M}^{-1}$.

\subsection{Ekstraksi Template Diazepam dari Sorben IP Cara Sonikasi}

Ekstraksi ini bertujuan untuk melepaskan ikatan antara template dengan monomer sehingga template terlepas dari polimer dan terbentuk rongga bekas template. Pelepasan template dapat dilakukan dengan pelarut polar atau pelarut asam yang mampu merusak ikatan non kovalen antara template dengan monomer. Tidak adanya serapan diazepam pada panjang gelombang tertentu menunjukkan bahwa diazepam sudah lepas dari sorben IP.

\subsection{Evaluasi Kemampuan Adsorpsi IP dan} NIP dengan Metode Batch

Evaluasi ini bertujuan untuk mengetahui tingkat adsorpsi sorben dalam berbagai jenis pelarut sehingga nantinya dapat disimpulkan pelarut yang dapat memberikan tingkat adsorpsi maksimum13. Pelarut yang digunakan adalah kloroform, asetonitril, dan dimetil sulfoksida (DMSO). Hasil evaluasi kemampuan adsorpsi dilihat pada Gambar 2.

Berdasarkan Gambar 2, IP Asam Metakrilat (MAA) mengadsorpsi diazepam $9,65 \% \pm 1,31 \%$ dan IP HEMA sebesar 7,8 $\% \pm 1,36 \%$ dalam pelarut asetonitril dan memiliki selisih paling besar dengan NIP sebagai kontrol. Adsorpsi dalam asetonitril akan digunakan untuk menentukan kapasitas adsorpsi sorben terhadap diazepam.

\subsection{Evaluasi Kapasitas Adsorpsi IP dan NIP dengan Metode Batch}

Evaluasi kapasitas adsorpsi ini dilakukan untuk mengetahui afinitas dari template (diazepam) dengan sorben IP serta indeks homogenitas dari sorben. Untuk mengetahui afinitas dan distribusi situs pengikatan maka dilakukan perhitungan terhadap isoterm Freundlich dan isoterm Langmuir. ${ }^{18}$ Hasil evaluasi kapasitas adsorpsi tercantum dalam Tabel 1.

Berdasarkan hasil kapasitas adsorpsi diketahui bahwa kapasitas adsorpsi IP dari monomer asam metakrilat lebih besar dibandingkan IP dari monomer HEMA. Sehingga IP monomer asam metakrilat memiliki hasil evaluasi kapasitas adsorpsi yang lebih baik dibandingkan IP monomer HEMA.

\subsection{Penentuan Selektivitas IP dan NIP-SPE dengan Metode Batch}

Pengerjaan penentuan selektivitas ini dilakukan untuk mengetahui selektivitas dari polimer MIP yang telah dibuat dibandingkan terhadap obat lain seperti alprazolam dan hidromorfon. Nilai selektivitas ditunjukkan dari imprinting factor (IF) nya seperti pada

Tabel 2. Hasil penentuan selektivitas polimer MIP

\begin{tabular}{|c|c|c|c|c|c|c|}
\hline \multirow[t]{2}{*}{ Zat } & \multicolumn{4}{|c|}{ KD (Konstanta Distribusi) } & \multirow[t]{2}{*}{ IF } & \multirow[t]{2}{*}{$\mathrm{R}^{2}$} \\
\hline & $\mathrm{AM}$ & IF HEMA & $\mathrm{R}^{2}$ & $\mathrm{~b}$ & & \\
\hline & IP AM & NIP AM & IP HEMA & NIP HEMA & & \\
\hline Diazepam & 26,72 & 12,56 & 21,17 & 17,52 & 2,13 & 1,21 \\
\hline Alprazolam & 19,08 & 38,93 & 12,57 & 26,47 & 0,49 & 0,47 \\
\hline Hidromorfon & 48,03 & 29,54 & 40,90 & 58,58 & 1,63 & 0,69 \\
\hline
\end{tabular}


Tabel 3. Hasil analisis FTIR sorben IP dan NIP monomer asam metakrilat

\begin{tabular}{|c|c|c|c|}
\hline \multicolumn{3}{|c|}{ Bilangan Gelombang $(\mathrm{cm}-1)$} & \multirow[t]{2}{*}{ Gugus Fungsi } \\
\hline $\begin{array}{c}\text { Sorben IP sebelum } \\
\text { ekstraksi }\end{array}$ & $\begin{array}{l}\text { Sorben IP sesudah } \\
\text { ekstraksi }\end{array}$ & Sorben NIP & \\
\hline 3499,80 & 3537,45 & 3496,94 & -O-H stretching \\
\hline 2968,80 & 2989,66 & 2989,66 & $\mathrm{C}-\mathrm{H}$ stretching \\
\hline 1732,08 & 1734,01 & 1724,36 & $\mathrm{C}=\mathrm{O}$ stretching \\
\hline 1623,54 & 1635,64 & 1629,85 & $\mathrm{C}=\mathrm{C}$ stretching \\
\hline 1462,04 & 1465,90 & 1458,18 & $\mathrm{C}-\mathrm{H}$ bending \\
\hline 1161,15 & 1159,22 & 1157,29 & C-O stretching \\
\hline
\end{tabular}

Tabel 2.

3.6. Karakterisasi secara Fisika Sorben MIP dan NIP-SPE dengan Fourier Transform Infra Red (FTIR), dan Scanning Electron Microscope (SEM) FTIR digunakan untuk melihat gugus fungsi yang terdapat dalam sorben IP dan NIP terutama gugus fungsi dari diazepam. Sedangkan SEM digunakan untuk pengamatan morfologi dari sorben MIP dan NIP. ${ }^{15}$ Hasil FTIR dapat dilihat pada Tabel 3 dan Tabel 4, sedangkan hasil SEM dapat dilihat pada Gambar 3 .

\section{Pembahasan}

4.1. Penentuan Konstanta Asosiasi Monomer-Template dengan Menggunakan Spektrofotometer UV Visible

Diazepam (pKa : 3,4) akan berikatan lebih kuat dengan asam metakrilat karena sifat keasaman asam metakrilat $(\mathrm{pKa}: 4,65)$ lebih asam dibandingkan HEMA (pKa : 13,82). ${ }^{19}$ Hasil dari penentuan $\mathrm{Ka}$ memperlihatkan bahwa Ka dari asam metakrilat lebih besar dari HEMA yang artinya kekuatan ikatan interaksi antara asam metakrilat dengan diazepam lebih besar dibandingkan HEMA dengan diazepam.

4.2. Sintesis Imprinted Polymer (IP) dan Non Imprinted Polymer (NIP) dengan Metode Polimerisasi Ruah

Sintesis sorben MIP dan NIP-SPE diazepam dalam kloroform dengan metode polimerisasi ruah. Polimerisasi ruah memiliki kelebihan yaitu preparasi yang mudah dan tidak memerlukan alat yang canggih dalam penggunaannya. ${ }^{20}$ Sintesis ini dilakukan dengan rasio perbandingan template : monomer : cross linker yakni 1:4:20. Penggunaan monomer yang lebih banyak dibandingkan template untuk membentuk ikatan kompleks sehingga terbentuk rongga spesifik. Rasio template : monomer biasanya $1: 4 .^{21}$ Ikatan kompleks yang terbentuk membuat polimer menjadi lebih stabil namun jumlah monomer yang terlalu berlebihan dapat menyebabkan ikatan tidak spesifik dan mereduksi selektivitas polimer. ${ }^{22}$

\subsection{Evaluasi Kemampuan Adsorpsi IP dan} NIP dengan Metode Batch

Tabel 4. Hasil analisis FTIR sorben IP dan NIP monomer HEMA

\begin{tabular}{cccc}
\hline & \multicolumn{2}{c}{ Bilangan Gelombang $(\mathrm{cm}-1)$} & Gugus Fungsi \\
\cline { 2 - 3 } $\begin{array}{c}\text { Sorben IP sebelum } \\
\text { ekstraksi }\end{array}$ & $\begin{array}{c}\text { Sorben IP sesudah } \\
\text { ekstraksi }\end{array}$ & Sorben NIP & \\
\hline 3592,48 & 3499,87 & 3620,45 & -O-H stretching \\
2991,64 & 2958,80 & 2988,75 & C-H stretching \\
1734,04 & 1732,08 & 1735,01 & C=O stretching \\
1634,09 & 1637,56 & 1625,66 & C=C stretching \\
1472,68 & 1462,04 & 1473,64 & C-H bending \\
1161,17 & 1159,22 & 1156,34 & C-O stretching
\end{tabular}




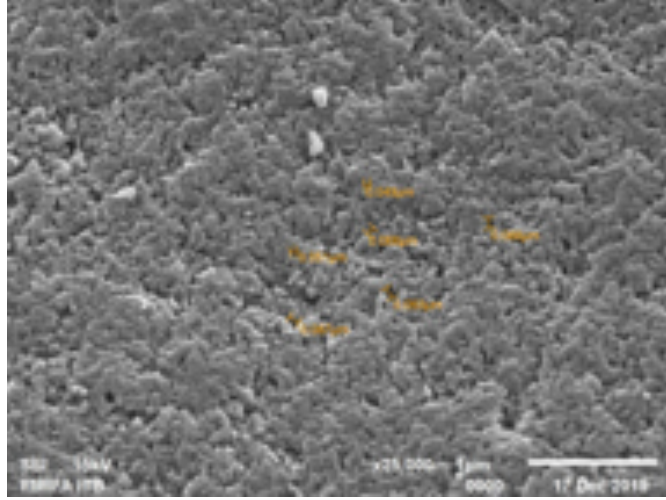

(a)

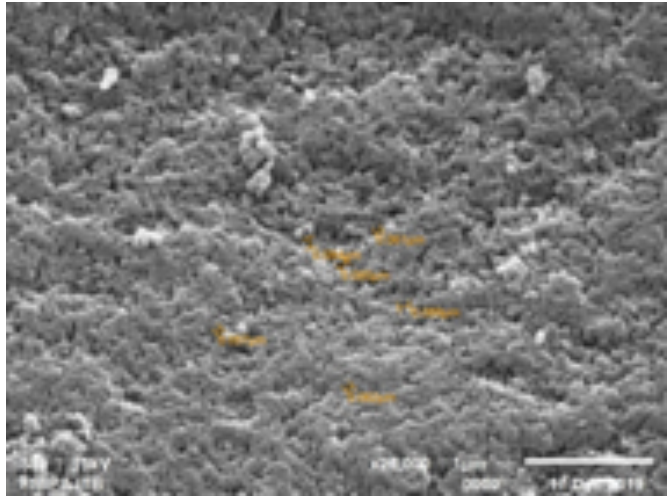

(b)

Gambar 3. (a) IP monomer asam metakrilat perbesaran $1 \mu \mathrm{m}$ x 25000 kali (b) NIP monomer asam metakrilat perbesaran $1 \mu \mathrm{m} \times 25000$ kali

Pengujian evaluasi kemampuan adsorpsi dilakukan terhadap jenis pelarut yang berbeda karena polimer memiliki kemampuan swelling (mengembang atau menyusut) berbeda terhadap pelarut yang berbeda. Kloroform dipilih karena sifat non polarnya dan diazepam larut dalam kloroform $^{23}$ Asetonitril (ACN) dan DMSO digunakan karena sifat polar aprotik yang memiliki konstanta dielektrik berbeda (ACN $=38.8$ dan DMSO = 47) dapat menguji efisiensi interaksi antara template dengan monomer21. Berdasarkan Gambar 2, IP MAA mengadsorpsi diazepam $9,65 \% \pm 1,31 \%$ dan IP HEMA sebesar 7,8 \% $\pm 1,36 \%$ dalam pelarut asetonitril dan memiliki selisih paling besar dengan NIP sebagai kontrol. Adsorpsi dalam asetonitril inilah yang kemudiak dilanjutkan untuk menentukan kapasitas adsorpsi sorben terhadap diazepam.

\subsection{Evaluasi Kapasitas Adsorpsi IP dan NIP dengan Metode Batch}

Mekanisme adsorpsi IP dan NIP dapat ditentukan melalui adsorpsi Isoterm Freundlich maupun Langmuir. Isoterm Frendlich digunakan ketika asumsi isoterm pada permukaan heterogen. Sedangkan Isoterm Langmuir diasumsikan bahwa setiap sisiadsorpsimemilikikesamaanuntukmolekul template yang hanya terjadi di permukaan tunggal (monolayer). Kedua persamaan ini akan dibandingkan terhadap besarnya nila R2 dari masing-masing isoterm. ${ }^{24}$ Selain itu, nilai $\mathrm{b}$ dan $\mathrm{K}$ yang negatif mengasumsikan bahwa sorben tidak mengikuti isoterm Langmuir. ${ }^{25}$
Pada isoterm Freundlich, nilai $\mathrm{m}$ menunjukkan indeks homogenitas, ketika nilainya mendekati 1 maka penyerapan yang terjadi homogen namun jika mendekati 0 maka sorben lebih heterogen. ${ }^{26}$ Nilai m pada kisaran 2-10 berarti kemampuan adsorpsi baik, rentang 1-2 kemampuan adsorpsi cukup sulit, dan $\mathrm{m}<1$ maka adsorpsi buruk..$^{25}$ Sedangkan, nilai A menunjukkan kapasitas sorben, ketika semakin tinggi angka yang didapatkan maka semakin besar kapasitas sorben dalam mengikat analit. ${ }^{26}$ Pada isoterm Langmuir, nilai $\mathrm{b}$ menunjukkan kapasitas adsorpsi dan $\mathrm{K}$ menunjukkan konstanta Langmuir yang dikorelasikan. Jika luas permukaan besar atau monolayer maka pori akan menghasilkan kapasitas adsorpsi yang besar pula. ${ }^{27}$ Berdasarkan hasil kapasitas adsorpsi diketahui bahwa kapasitas adsorpsi IP dari monomer asam metakrilat lebih besar dibandingkan IP dari monomer HEMA. Sehingga IP monomer asam metakrilat memiliki hasil evaluasi kapasitas adsorpsi yang lebih baik dibandingkan IP monomer HEMA.

\subsection{Penentuan Selektivitas IP dan NIP dengan Metode Batch \\ Nilai IF terhadap diazepam lebih besar} dibandingkan hidromorfon dan alprazolam. Nilai IF dari IP dengan monomer asam metakrilat lebih besar dibandingkan HEMA. Semakin besar nilai IF maka semakin selektif sorben terhadap zat tersebut. Rendahnya nilai IF dapat juga disebabkan karena rendahnya nilai konstanta asosiasi (Ka) yang berarti 
rendahnya kekuatan ikatan antara monomer dengan template sehingga penyerapan yang terjadi pada penentuan selektivitas pun rendah. Pada hasil dengan alprazolam dan hidromorfon yang mempengaruhi hasil tersebut adalah struktur zat dengan bentuk tiga dimensi dari zat - zat tersebut memiliki kemiripan.

\subsection{Karakterisasi secara Fisika Sorben IP} dan NIP dengan Fourier Transform Infra Red (FTIR), dan Scanning Electron Microscope (SEM)

Penentuan karakterisasi menggunakan FTIR untuk mengamati kesempurnaan dalam proses polimerisasi yang ditandai dengan tidak adanya serapan yang dihasilkan dari gugus vinil. Pada hasil pengukuran FTIR diketahui tidak adanya keberadaan gugus vinil yang memberikan bentuk spektrum berupa puncak doublet (puncak kembar) pada bilangan gelombang $1000 \mathrm{~cm}-1$ dan $900 \mathrm{~cm}-1$ pada $=\mathrm{C}-\mathrm{H}$ bending, dapat diinterpretasikan bahwa monomer belum bereaksi sempurna dalam polimerisasi. $^{28}$

Pada hasil dari SEM didapatkan ukuran rongga pada IP yaitu $0,049-0,093 \mu \mathrm{m}$ dan NIP sebesar 0,057 - 0,089 $\mu \mathrm{m}$ menunjukkan MIP memiliki rongga yang cenderung lebih heterogen dibandingkan NIP tetapi hal ini berkebalikan dengan simpulan hasil isoterm Freundlich yang menunjukkan bahwa IP lebih homogen dibandingkan dengan NIP. Hal ini terjadi karena rongga yang terbentuk sangat kecil dan memiliki skala yang cukup dekat antara IP dan NIP. Pada IP akan terbentuk rongga yang diakibatkan lepasnya template dan menyebabkan kapasitas adsorpsi dari IP lebih besar dibandingkan dengan NIP. Bentuk dan ukuran yang seragam dari polimer dapat menguntungkan dalam interaksi antara monomer dan template. ${ }^{29}$ Morfologi dari bentuk polimer sangat dipengaruhi oleh metode polimerisasi. ${ }^{30}$ Proses penumbukkan dalam polimerisasi ruah dapat menghasilkan bentuk dan ukuran yang tidak beraturan. Selain itu juga menghasilkan distribusi yang cenderung heterogen dalam polimer. ${ }^{31}$

\section{Simpulan}

MI-SPE diazepam dengan monomer
MAA dan HEMA memiliki kinerja analitik dengan kapasitas adsorpsi IP monomer asam metakrilat sebesar 7,95 x $10^{-5} \mathrm{mg} / \mathrm{g}$ dengan nilai IF sebesar 2,13. Sedangkan pada IP monomer HEMA kapasitas adsorpsi sebesar $7,47 \times 10^{-6} \mathrm{mg} / \mathrm{g}$ dengan nilai IF sebesar 1,21. Nilai IF dari diazepam yang lebih besar dibandingkan dengan alprazolam memperlihatkan selektivitas yang baik dari polimer IP terhadap zat dalam satu golongan. Selain itu, pada MI-SPE diazepam dengan monomer MAA menggunakan polimerisasi ruah memiliki polimer dengan bentuk tidak beraturan dan ukuran rongga lebih kecil dari $1 \mu \mathrm{m}$. Selain itu, ukuran rongga pada IP MAA lebih heterogen dibandingkan NIP.

\section{Daftar Pustaka}

1. DiPiro, J.T., Wells,B.G., Schwinghammer, T.L. \& DiPiro, C.V., Pharmacotherapy Handbook. 9th Ed., New York : Mc Graw Hill. 2015. 148-155

2. Fu, X.W., Yang, Q., Zhou, Q., Lin.Q., and Wang, C. Template-Monomer Interaction in Molecular Imprinting: Is the Strongest the Best?. Open Journal of Organic Polymer Materials, 2015; 5:58-68

3. Jann, M., Kennedy, WK., Lopez, G. , Benzodiazepines : a major component in unintentional prescription drugs overdosis with analgesics,Journal Pharmacy Practise, 2014; 27 (1): 5-16. https://doi. org/10.1177/0897190013515001

4. BPOM, RI. 2016. Laporan Tahunan Tersedia online melalui website www. pom.go.id/new/admin/dat/20171127/ laptah2016.pdf [diakses pada tanggal 29 Juli 2019]. 2016. 91.

5. Mikomangwa, Wilgilya Padili, Nassoro A. Madende, Manase Kilonzi, Hamu Joseph Mlyuka, Pacifique Ndayishimiye, Alphonce Ignace Marealle, and Ritah Mutagonda. Unlawful dispensing practice of diazepam: a simulated client approach in community pharmacies in the northwest of Dar-esSalaam region, Tanzania. BMC Health Services Research, 2019; 19 (571). http://doi.org/10.1186/s12913019-4421-6

6. Jones, AW., and Holmgren, A. 
Concentrations of Diazepam and Nordiazepam in 1000 Blood Samples From Apprehended DriversTherapeutic Use or Abuse of Anxiolytics?. Journal of Pharmacy Practice, 2012; 26 (3): 198-203. https:// doi.org/10.1177/0897190012451910

7. Uzun, L., Uzek R., Senel, S., Say R. Denizli., A. Chiral recognition of proteins having L-histidine residues on the surface with lanthanide ion complex incorporatedmolecularly imprinted fluorescent nanoparticles. Mater Sci. Eng. C Vol. 2014; 33: 3432-3439.

8. Yanti, T Nurhayati, I Royani, Widayani, and Khairurrijal. Synthesis and characterization of MAA-based molecularly imprinted polymer (MIP) with D-glucose template. Journal of Physics: Conference Series 2016; 739. (1):1-7. https://doi.org/10.1088/17426596/739/1/012143

9. Yang, S., Yonghui W., Yingda J., Shuang L., and Wei L. Molecularly Imprinted Polymers for the Identification and Separation of Chiral Drugs and Biomolecules. Polymers, 2016; $8(216)$ :1-16. https://doi.org/10.3390/ polym 8060216

10. Surikumaran, H., Sarifah M., and Norazilawati MS. Molecular Imprinted Polymer of Methacrylic Acid Functionalised $\beta$-Cyclodextrin for Selective Removal of 2,4-Dichlorophenol. Int. J. Mol. Sci. 2014; 15: 6111-6136. https://doi.org/10.3390/ijms15046111

11. Gursoy, M., Ucar T., Tosun, Z., and Karaman M. Initiation of 2-Hydroxyethyl Methacrylate Polymerization by TertButyl Peroxide in a Planar PECVD System. Plasma Processes and Polymer, 2016:13 (4): 438-446. https://doi. org/10.1002/ppap.201500091

12. Thordarson, Pall. Determining association constants from titration experiments in supramolecular chemistry. Chem. Soc. Rev.. 2011;40:1305-1323. https://doi. org/10.1039/c0cs00062k.

13. Nurhayati, T., Yanti, I. Royani, Widayani dan Khairurrijal. Syntesis and Study of
Guest-Rebinding of MIP Based on MAA Prepared using Theophylline Template. Journal of Physics : Conference Series. 2016; 739: 1-7. https://doi. org/10.1088/1742-6596/739/1/012127

14. Ansari, Saeedeh, and A. Ghorbani. Moleculary Imprinted Polymers (MIP) for Selective Solid Phase Extraction of Celecoxib in Urine Sampeles Followed by High Performance Liquid Chromatography. Journal of Chemical Health Risks. 2017; 7 http//:doi. org/10.22034/JCHR.2017.544184

15. Hasanah, A.N., Rahmana E.K dan Slamet I. Synthesis and Application of Glibenclamide Imprinted Polymer for Solid Phase Extraction in Serum Samples Using Itaconic Acid as Functional Monomer. Journal of Applied Sciences. 2015; 15 (11): 1288-1296. https://doi. org/10.3923/jas.2015.1288.1296

16. Hasanah, A. N., Tridessy, N., Wijaya, N., Kartasasmita, R.E., Ibrahim, S., others. Study of The Binding Ability of Molecular Imprinted Solid Phase Extraction for Glibenclamide by Optimizing Template: Monomer: Crosslinker Ratio. Int. J. Chem. Sci. 2014;12 (3): 863-870. ISSN 0972-768X

17. Nguyen, J. N. T. and Harbison A. M., Scanning Electron Microscopy Sample Preparation and Imaging. Method Mol. Biol. 2017;1606:71-84. http://doi. org/10.1007/978-1-4939-6990-6_5.

18. Umpleby, R.J. II., Baxter SC, Rampey AM, Rushton GR, Chen Y and Shimizu KD. Characterization of the heterogeneous binding site affinity distributions in molecularly imprinted polymers. J Chromatogr B Analyt Technol Biomed Life Sci. 2004; 804 (1) : 141-149. https:// doi.org/10.1016/j.jchromb.2004.01.064

19. Pataer, P., Turghun M., Yunusjan T., Wenwi Y., Sailemayi A., Muyasier W., and Lingxin Xhen. Preparation of a stoichiometric molecularly imprinted polymer for auramine $\mathrm{O}$ and application in solid-phase extraction. Journal of Separation Science 2019; 42 :1634-1643. https://doi.org/10.1002/jssc.201801234 
20. Yan, H., and Kyung Ho Row. Characteristic and Synthetic Approach of Molecularly Imprinted Polymer. Int. J. Mol. Sci. 2006; 7: 155-178. https://doi. org/10.3390/i7050155

21. Vasapollo, G., Robert Del S., Lucia M., Maria R., Anna S., Sonia S., and Giuseppe M. Molecularly Imprinted Polymers: Present and Future Prospective. Int. J. Mol. Sci. 2011; 12: 5908-5945. https:// doi.org/10.3390/ijms12095908

22. Azalina, MN., K L Chua, and I Noorhidayah. Theoretical and experimental study of valine molecular imprinted polymer using sol-gel process on silica microparticles surface. IOP Conf. Ser.: Mater. Sci. Eng. 2018; 458: 012012. https://doi.org/10.1088/1757899X/458/1/012012

23. Chen, Lingxin., Shoufang $\mathrm{Xu}$, and Jinhua Li.. Recent advances in molecular imprinting technology: current status, challenges and highlighted applications. Chem. Soc. Rev. 2011; 40:2922-2942. https://doi.org/10.1039/C0CS00084A

24. Amin, S., Sophi D., and Slamet Ibrahim. Interaction Study, Synthesis and Characterization of Molecular Imprinted Polymer Using Functional Monomer Methacrylate Acid and Dimethylamylamine as Template Molecule. Jurnal Ilmu Kefarmasian Indonesia 2018; 16(1):12-19. https://doi. org/10.35814/jifi.v16i1.430

25. Shikuku, VO., Renato Z., Chrispin OK., Filipe FD., Nelson MGB., and Osmar DP. Single and binary adsorption of sulfonamide antibiotics onto ironmodified clay: linear and nonlinear isotherms, kinetics, thermodynamics, and mechanistic studies. Applied Water
Science, 2018;8 (6):133 https://doi. org/10.1007/s13201-018-0825-4

26. Hasanah, A.N., Traju Ningtias D.U., and Rimadani P. Synthesis of AtenololImprinted Polymers with Methyl Methacrylateas Functional Monomer in Propanol Using Bulk and Precipitation Polymerization Method. Journal of Analytical Methods in Chemistry 2019; Volume 2019: 1-7. https://doi. org/10.1155/2019/9853620

27. Ayawei, N., Augustus NE., and Donbebe W. Modelling and Interpretation of Adsorption Isoterm. Journal of Chemistry, 2017;1: 1-11. https://doi. org/10.1155/2017/3039817

28. Ansari, Saeedeh, and A. Ghorbani. Moleculary Imprinted Polymers (MIP) for Selective Solid Phase Extraction of Celecoxib in Urine Sampeles Followed by High Performance Liquid Chromatography. Journal of Chemical Health Risks. 2017; 7. http//:doi. org/10.22034/JCHR.2017.544184

29. Bachtiar, A., Showkat AB., and Syed RS. Synthesis and characterization of molecular imprinting polymer for the removal of 2-phenylphenol from spiked blood serum and river water. Chem. Biol. Technol. Agric. 2019; 6 (15) : 2-10.https:// doi.org/10.1186/s40538-019-0152-5

30. Bhawani,SA., Tham Soon S., and Mohammad Nasir MI. Synthesis of molecular imprinting polymers for extraction of gallic acid from urine. Chemistry Central Journal, 2018;12 (19): 334. https://doi.org/10.1186/s13065-0180392-7

31. Kumbar, S., Laurencin, C. and Deng, M. Natural and Synthetic Biomedical Polymers. Elsevier Science. 2014. 